\title{
PHASE EVOLUTION IN AND CREEP PROPERTIES OF NB-RICH NB-SI-CR EUTECTICS
}

Florian Gang, Alexander Kauffmann, Martin Heilmaier

Institute for Applied Materials (IAM-WK), Karlsruhe Institute of Technology (KIT), Engelbert-ArnoldStr. 4, D-76131 Karlsruhe, Germany

corresponding author: Florian Gang, florian.gang@kit.edu

This manuscript is intended for publication in the MMTA special issue on the "TMS 2017 Materials for High Temperature Applications: Next Generation Superalloys and Beyond" symposium.

\begin{abstract}
In this work, the $\mathrm{Nb}$-rich ternary eutectic in the $\mathrm{Nb}-\mathrm{Si}-\mathrm{Cr}$ system has been experimentally determined to be $\mathrm{Nb}-10.9 \mathrm{Si}-28.4 \mathrm{Cr}$ (in at.\%). The eutectic is composed of three main phases, $\mathrm{Nb}$ solid solution $\left(\mathrm{Nb}_{\mathrm{ss}}\right), \beta-\mathrm{Cr}_{2} \mathrm{Nb}$ and $\mathrm{Nb}_{9}(\mathrm{Si}, \mathrm{Cr})_{5}$. The ternary eutectic microstructure remains stable for several hundred hours at a temperature up to $1200^{\circ} \mathrm{C}$. At $1300^{\circ} \mathrm{C}$ and above, the silicide phase $\mathrm{Nb}_{9}(\mathrm{Si}, \mathrm{Cr})_{5}$ decomposes into $\alpha-\mathrm{Nb}_{5} \mathrm{Si}_{3}, \mathrm{Nb}_{\text {ss }}$ and $\beta-\mathrm{Cr}_{2} \mathrm{Nb}$. Under creep conditions at $1200^{\circ} \mathrm{C}$, the alloy deforms by dislocation creep while the major creep resistance is provided by the silicide matrix. If the silicide phase is fragmented and, thus, its matrix character is destroyed by prior heat treatment (e.g. at 1500 ${ }^{\circ} \mathrm{C}$ for $100 \mathrm{~h}$ ), creep is mainly controlled by the Laves phase $\beta-\mathrm{Cr}_{2} \mathrm{Nb}$, resulting in increased minimum strain rates. Compared to state of the art Ni-based superalloys, the creep resistance of this three phase eutectic alloy is significantly higher.
\end{abstract}

Keywords: eutectic alloys, niobium silicides, intermetallics, refractory based alloys, creep 
Due to their high melting point and relatively low density, $\mathrm{Nb}$-Si based alloys are promising novel materials for high temperature structural applications [1, 2]. Unfortunately, good mechanical strength and oxidation resistance at elevated temperatures, as well as sufficient fracture toughness at ambient temperature, are difficult to achieve simultaneously in a satisfactory manner, as the improvement of one property usually comes along at the expense of the other. This challenge may be met by e.g. combining different phases with complementary properties in a fine eutectic microstructure. For example, in the $\mathrm{Nb}-\mathrm{Si}$ binary system, the binary eutectic $\mathrm{Nb}-18 \mathrm{Si}$ (in at.\%) showed a combination of high creep strength subsequent to directional solidification [3] with reasonable fracture toughness [4] due to the presence of the silicide and $\mathrm{Nb}$ solid solution $\left(\mathrm{Nb}_{\mathrm{ss}}\right)$, respectively. However, this alloying system did not provide acceptable oxidation resistance, as the bulky, porous and non-adherent oxide $\mathrm{Nb}_{2} \mathrm{O}_{5}$ is formed. Hence, further alloying additions are necessary to suppress the formation of $\mathrm{Nb}_{2} \mathrm{O}_{5}$. For example, $\mathrm{Ti}, \mathrm{Al}, \mathrm{Sn}$ and $\mathrm{Cr}$ are known to increase the oxidation resistance [5-8]. However, only the system $\mathrm{Nb}$-Si-Cr features a $\mathrm{Nb}$-rich ternary eutectic as a prerequisite for later directional solidification.

For this reason, the model system $\mathrm{Nb}-\mathrm{Si}-\mathrm{Cr}$ was selected, where $\mathrm{Cr}$ is added to mainly improve the oxidation resistance, by replacing the fast forming, bulky, non-adherent oxide $\mathrm{Nb}_{2} \mathrm{O}_{5}$ by dense, adherent $\mathrm{CrNbO}_{4}$ scales [9]. Si is known to improve the creep properties by formation of silicide phases while $\mathrm{Nb}$ solid solution $\left(\mathrm{Nb}_{\mathrm{ss}}\right)$ provides suitable fracture toughness. However, a literature survey reveals contradictory information on the exact composition of the ternary eutectic in this system. In 2005, Shao calculated the ternary eutectic composition to be $\mathrm{Nb}-12 \mathrm{Si}-25 \mathrm{Cr}$ [10] (in at.\%) using CALPHAD. In contrast, Bewlay et al. experimentally assessed the Nb-Si-Cr system in 2009 to determine the ternary eutectic composition to be close to $\mathrm{Nb}-8.7 \mathrm{Si}-33.1 \mathrm{Cr}$ [11]. Therefore, the exact location of the ternary eutectic is critically reviewed in this study with samples of different appropriate alloy compositions produced by arc melting. The identified composition of the ternary eutectic is thoroughly assessed in terms of phase evolution, as well as microstructure and phase stability. Moreover, the creep behavior at the potential operating temperature of $1200^{\circ} \mathrm{C}$ is assessed.

\section{Experimental}

To determine the ternary eutectic composition, different alloys were synthesized from elemental granules (Cr, purity 99,0 wt.\%; Si purity 99,9999 wt.\%) and slug (Nb, purity 99,8 wt.\%) using an arc melter AM/0.5 (Edmund Buehler GmbH, Hechingen, Germany) with tungsten electrode. Chemical analysis of cast ingots (mass $30 \mathrm{~g}$ ) was carried out by means of inductively coupled plasma optical emission spectrometry (ICP-OES). For heat treatments and microstructure examinations, the ingots were cut into smaller pieces using electro discharge machining. Heat treatments were performed in a high temperature furnace Gero HTRH 70-600/18 (Carbolite Gero GmbH, Neuhausen, Germany) under Ar atmosphere. Metallographic samples were hot-mounted in "Duroplast" resin (ATM GmbH, Mammelzen, Germany) using a Simplimet 1000 (Buehler, Lake Bluff, IL, USA), prior to grinding using $\mathrm{SiC}$ paper with successively decreasing particle size and finally polished with a diamond suspension. To prepare samples for electron backscatter diffraction (EBSD), two additional semiautomatic polishing steps with both non-crystallizing, pH-neutral OPS (10 minutes) and alkaline stabilized OPS (1 minute) were performed to remove remaining surface-near plastic deformation by the prior polishing steps.

The microstructure was examined using an SEM EVO 50 (Carl Zeiss AG, Oberkochen, Germany) in backscattered-electron mode (BSE) to reveal the different phases. Phase fractions (vol.\%, as material is expected to be isotropic) were determined on at least five SEM-BSE images each using the software ImageJ for quantitative image analysis by threshold segmentation. Local phase compositions were determined applying electron probe micro analysis (EPMA). Either the aforementioned SEM was used for standardless energy-dispersive spectroscopy (EDS) measurements or a SEM JEOL JXA8100 (JEOL GmbH, Freising, Germany) was employed for wavelength-dispersive spectroscopy (WDS) measurements using the standards $\mathrm{J} 13 \_\mathrm{Cr}, \mathrm{J} 13$ Si, $\mathrm{J} 13 \mathrm{ZrO}_{2}$ and $9033 \mathrm{Nb}$. EBSD was performed using an EDAX DigiView camera on a Zeiss Auriga 60 SEM (Carl Zeiss AG, Oberkochen, Germany). For analysis of the determined EBSD patterns, a commercial software provided by EDAX was used. Creep tests on cuboidal samples (size $3 \mathrm{~mm} \times 3 \mathrm{~mm} \times 5 \mathrm{~mm}$ ) were performed in compression in an electro-mechanical universal testing machine Zwick Z100 (Zwick GmbH, Ulm, Germany) with attached vacuum furnace (Maytec $\mathrm{GmbH}$, Singen, Germany) at constant true stress at $1200^{\circ} \mathrm{C}$ in vacuum. All creep experiments were terminated before failure of the samples. 


\section{Results and Discussion}

\section{Determination of the ternary eutectic}

Figure 1 compares the microstructures of the two different ternary eutectic compositions suggested in the literature [10,11]. It becomes obvious that $\mathrm{Nb}-12 \mathrm{Si}-25 \mathrm{Cr}$ (Figure 1a) is not a ternary eutectic, as a significant amount of primary solidifying $\mathrm{Nb}_{\mathrm{ss}}$ (light-grey phase, phase fraction (25.1 \pm 3.2) vol.\%) is located between a subsequently solidified two-phase eutectic microstructure. According to EDS measurements, this eutectic consists of $\mathrm{Nb}_{\mathrm{ss}}$ and a ternary silicide phase in the compositional range of $\mathrm{Nb}_{9}(\mathrm{Si}, \mathrm{Cr})_{5}$ (grey phase). However, at equilibrium, $\alpha-\mathrm{Nb}_{5} \mathrm{Si}_{3}$ silicide is expected according to calculations by Shao [10]. The determined $\mathrm{Nb}_{9}(\mathrm{Si}, \mathrm{Cr})_{5}$ silicide composition matches quite well with the one reported by Bewlay et al. for the phase present in the vicinity of the ternary eutectic [11]. This mismatch between calculation and experiment might be due to an incomplete Calphad database, in which the ternary silicide has not been implemented. Despite of some Cr-rich segregations (dark grey phase), no other phases are detectable in Figure 1a.

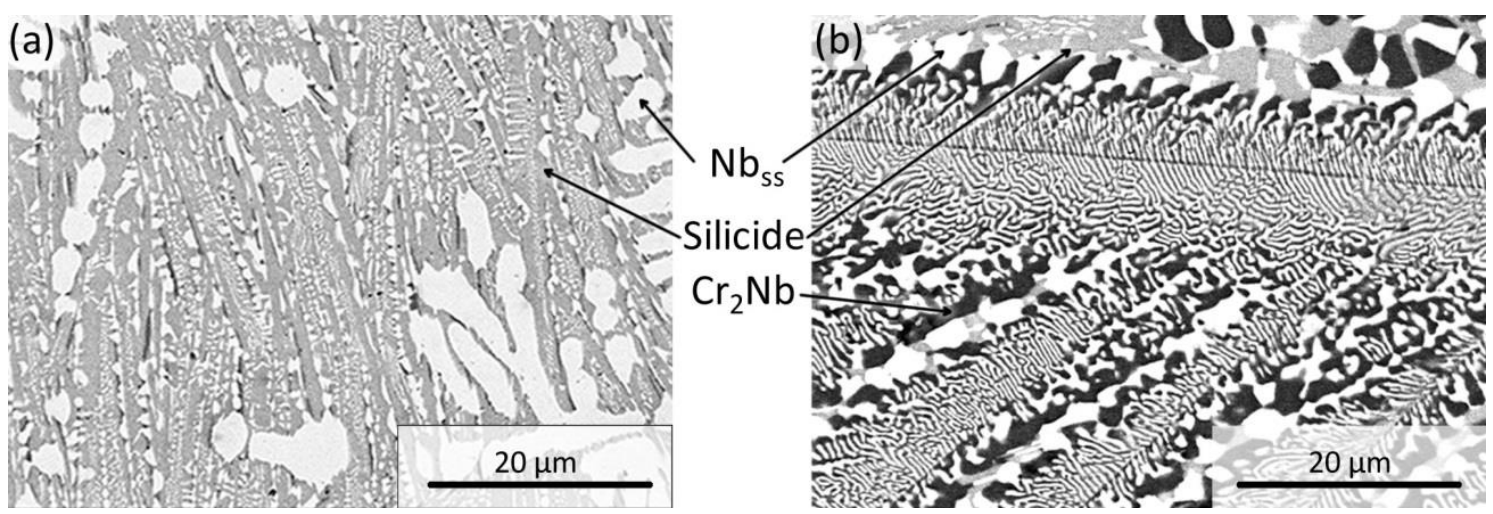

Figure 1: SEM-BSE micrographs of the alloys (a) Nb-12Si-25Cr and (b) $\mathrm{Nb}-8.7 \mathrm{Si}-33.1 \mathrm{Cr}$, both in as cast condition

In contrast, the second proposed composition $\mathrm{Nb}-8.7 \mathrm{Si}-33.1 \mathrm{Cr}$, shown in Figure 1b, does not exhibit primary solidification of a single phase, indicating close proximity to the ternary eutectic composition. The microstructure is characterized by two distinct features:

(i) very fine two-phase lamellar eutectic cells, in which a coupled growth of $\mathrm{Nb}_{\mathrm{ss}}$ (white phase) and $\mathrm{Cr}_{2} \mathrm{Nb}$ (dark-grey phase) occurs;

(ii) in between, coarse regions consisting of three different phases, i.e. $\mathrm{Nb}_{\mathrm{ss}}$ (white phase), $\mathrm{Cr}_{2} \mathrm{Nb}$ (black phase) and a third undetermined silicide phase (light-grey).

This ternary phase does not correlate with the compositional range of $\mathrm{Nb}_{9}(\mathrm{Si}, \mathrm{Cr})_{5}$, as its chemical composition was determined to be $(50.2 \pm 0.5)$ at. \% Nb,(15.2 \pm 0.2$)$ at.\% $\mathrm{Si}$ and $(34.6 \pm 0.3)$ at.\% $\mathrm{Cr}$, which does not match with any known phase in the $\mathrm{Nb}$-Si-Cr system. However, the identification and the study of this unknown phase are beyond the scope of the present study and will not be addressed hereafter. Therefore, $\mathrm{Nb}-8.7 \mathrm{Si}-33.1 \mathrm{Cr}$ is also not the exact ternary eutectic composition.

To reduce the gap between literature results and experiments regarding the ternary eutectic composition, a triangulation scheme was carried out by examining compositions in the vicinity of $\mathrm{Nb}$ 8.7Si-33.1Cr. Starting from this composition, either the Si or $\mathrm{Cr}$ content was varied to achieve primary solidification of either $\mathrm{Nb}_{\mathrm{ss}}$ or $\mathrm{Cr}_{2} \mathrm{Nb}$. The examined compositions are given in Table 1 and are additionally plotted in the partial liquidus projection in Figure 2. Comparison between nominal composition and actual composition reveals no deviation within the range of the measurement uncertainty (standard deviation SD $\leq 0.4$ at. $\%$ for $\mathrm{Si}$, and SD $\leq 0.45$ at. $\%$ for $\mathrm{Cr}$ ). For this reason, only nominal compositions will be used in the following. 


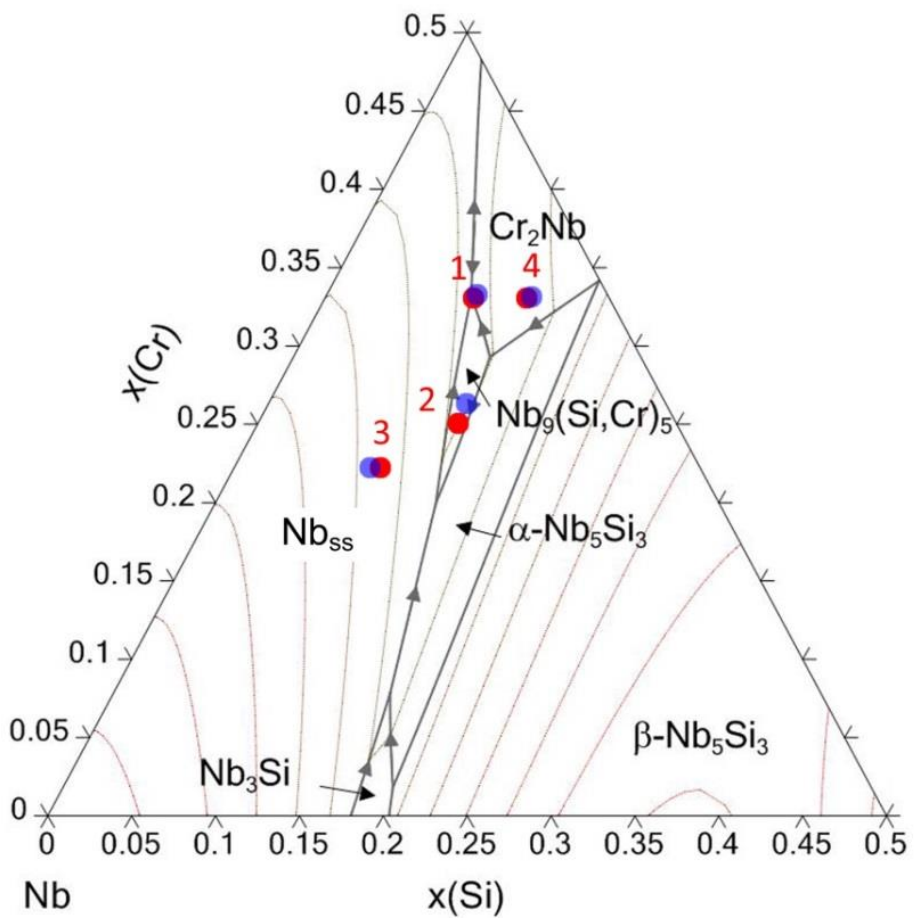

Figure 2: Partial liquidus projection of the Nb-Si-Cr system, including isothermal lines (calculated with PANDAT employing the PanNb database). Compositions according to the numbers are listed in Table 1. The red dots symbolize the nominal composition; blue ones represent the actual composition.

The microstructures of Alloys 1 (Nb-8.7Si-33.1 Cr) and $2(\mathrm{Nb}-12 \mathrm{Si}-25 \mathrm{Cr}$ ) have already been discussed. For Alloy $3(\mathrm{Nb}-8.7-22 \mathrm{Cr}), \mathrm{Nb}_{\mathrm{ss}}$ primary solidification is expected. Indeed, growth of $\mathrm{Nb}_{\mathrm{ss}}$ primary dendrites (white phase) is visible in Figure 3 a with a phase fraction of $(36.6 \pm 2.2)$ vol.\%. Moreover, ternary eutectic is present, comprising $\mathrm{Nb}_{\mathrm{ss}}, \mathrm{Cr}_{2} \mathrm{Nb}$ and $\mathrm{Nb}_{9}(\mathrm{Si}, \mathrm{Cr})_{5}$. The expected binary eutectic, which according to Figure 2 should consist of $\mathrm{Nb}_{\mathrm{ss}}$ and $\mathrm{Nb}_{9}(\mathrm{Si}, \mathrm{Cr})_{5}$, cannot clearly be separated from the ternary eutectic. Occasionally, binary eutectic structures of $\mathrm{Nb}_{\mathrm{ss}}+\mathrm{Cr}_{2} \mathrm{Nb}$ and $\mathrm{Cr}_{2} \mathrm{Nb}+\mathrm{Nb}_{9}(\mathrm{Si}, \mathrm{Cr})_{5}$ can be observed, which are not likely to form along the expected solidification path in equilibrium and may be attributed to segregation effects during solidification.

Conversely, Alloy 4 ( $\mathrm{Nb}-12 \mathrm{Si}-33-1 \mathrm{Cr})$, is expected to solidify from the $\mathrm{Cr}_{2} \mathrm{Nb}$ phase region. This feature is confirmed in Figure $3 \mathrm{~b}$, where $\mathrm{Cr}_{2} \mathrm{Nb}$ dendrites (black phase) are identified, having a phase fraction of $(23.6 \pm 0.6)$ vol.\%. Adjacent to primary dendrites, the binary eutectic $\mathrm{Nb}_{\mathrm{ss}}+\mathrm{Cr}_{2} \mathrm{Nb}$ is formed. Subsequently, the remaining melt solidifies by formation of ternary eutectic cells.
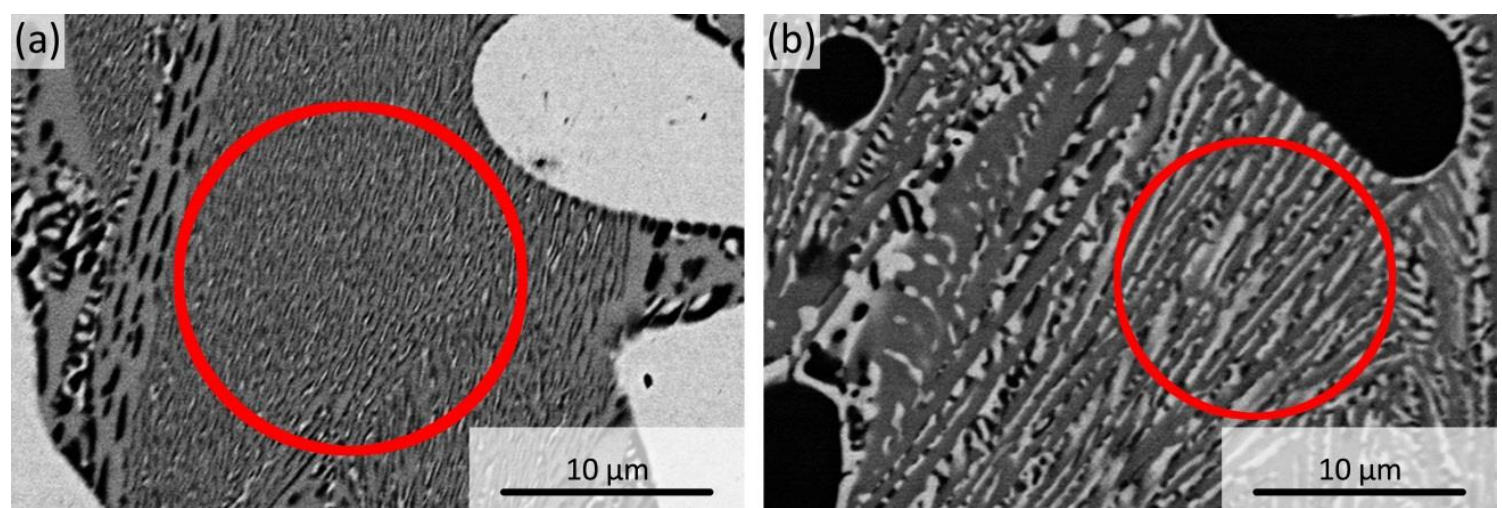

Figure 3: SEM-BSE micrographs of the alloys (a) Nb-8.7Si-22Cr and (b) Nb-12Si-33.1Cr. In both alloys ternary eutectic structures can be observed (marked with a red circle).

To determine the chemical composition of the ternary eutectic, EDS area scans of eutectic cells have been performed on Alloys 3 and 4. Exemplarily analyzed regions are marked by red circles in Figure 3 . Quantitative results for these scans are given in Table 2. The compositions for eutectic cells in both alloys are very similar. Accordingly, the "true" ternary eutectic composition has been approximated as $\mathrm{Nb}-10.9 \mathrm{Si}-28.4 \mathrm{Cr}$. This seems to be confirmed by the micrographs in Figure 4, where the microstructure of an alloy with actual composition of $\mathrm{Nb}-10.8 \mathrm{Si}-28.8 \mathrm{Cr}$ consists almost entirely of 
ternary eutectic cells. Within these cells, the silicide phase $\mathrm{Nb}_{9}(\mathrm{Si}, \mathrm{Cr})_{5}$ forms a discontinuous matrix (phase fraction $(67.7 \pm 4.2)$ vol.\%), which is clearly underlined by Figure $4 \mathrm{c}$ and orientation analysis that reveal uniform orientation of $\mathrm{Nb}_{9}(\mathrm{Si}, \mathrm{Cr})_{5}$ within the colonies. Between this silicide matrix, $\mathrm{Nb}_{\mathrm{ss}}$ and $\mathrm{Cr}_{2} \mathrm{Nb}$ grow in a coupled manner with phase fractions of $(14.6 \pm 4.7)$ vol.\% and $(17.7 \pm 4.9)$ vol.\%, respectively. Distributed along the cell boundaries, coarse regions of $\mathrm{Nb}_{9}(\mathrm{Si}, \mathrm{Cr})_{5}$ and the binary eutectic $\mathrm{Nb}_{\mathrm{ss}}+\mathrm{Cr}_{2} \mathrm{Nb}$ are present, which must have solidified before the ternary eutectic. As this slightly off-eutectic solidification occurs along the cell boundaries, the ternary eutectic composition was double-checked within the cells and the composition $\mathrm{Nb}-10.9 \mathrm{Si}-28.4 \mathrm{Cr}$ was confirmed. Chemical compositions of each individual phase were measured using WDS on the coarse regions. The results are given in Table 3. The actual chemical composition of $\mathrm{Nb}_{\mathrm{ss}}$ is in good agreement with previously published solubility limits of $\mathrm{Si}\left(2.4\right.$ at.\%) and $\mathrm{Cr}\left(16.0\right.$ at.\%) in an isothermal section at $1500{ }^{\circ} \mathrm{C}$ of the $\mathrm{Nb}-\mathrm{Si}-\mathrm{Cr}$ system [12]. For $\mathrm{Nb}_{9}(\mathrm{Si}, \mathrm{Cr})_{5}$, the measured composition is close to the stoichiometry of the phase.
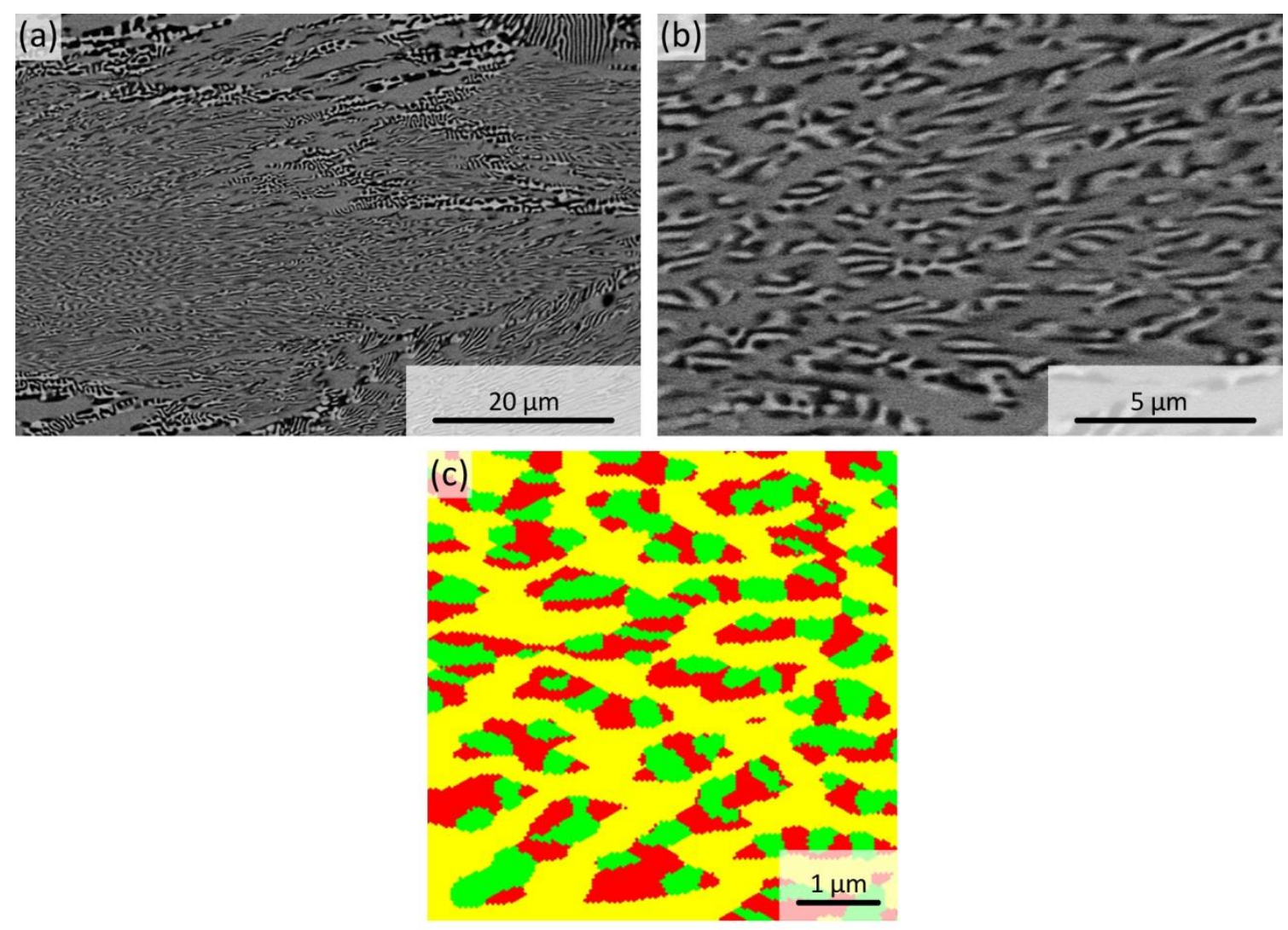

Figure 4: Micrographs of the ternary eutectic alloy Nb-10.9Si-28.4Cr: (a-b) SEM-BSE mode and (c) EBSD, false-color image of the phases $\mathrm{Nb}_{9}(\mathrm{Si}, \mathrm{Cr})_{5}$ (yellow), $\mathrm{Nb}_{\text {ss }}$ (green) and $\mathrm{Cr}_{2} \mathrm{Nb}$ (red).

In $\mathrm{Cr}_{2} \mathrm{Nb}$, Si is significantly substituting for $\mathrm{Cr}$. According to Ref. [13], up to 26 at.\% of Si can substitute $\mathrm{Cr}$, stabilizing the hexagonal high temperature modification $\beta-\mathrm{Cr}_{2} \mathrm{Nb}\left(\mathrm{C} 14, \mathrm{hP} 12, \mathrm{P} 6_{3} / \mathrm{mmc}\right)$ down to ambient temperature. In contrast, the hexagonal, binary $\beta-\mathrm{Cr}_{2} \mathrm{Nb}$ phase would transform into its cubic low temperature modification $\alpha-\mathrm{Cr}_{2} \mathrm{Nb}(\mathrm{C} 15, \mathrm{cF} 24, \mathrm{Fd} 3 \mathrm{~m})$ below $1600{ }^{\circ} \mathrm{C}$ for the binary $\mathrm{Nb}-\mathrm{Cr}$ system [14]. The presence of $\beta-\mathrm{Cr}_{2} \mathrm{Nb}$ in $\mathrm{Nb}-10.9 \mathrm{Si}-28.4 \mathrm{Cr}$ was additionally confirmed using EBSD; indexed diffraction patterns for all phases present in $\mathrm{Nb}-10.9 \mathrm{Si}-28.4 \mathrm{Cr}$ are shown in Figure 5. For the sake of simplicity, $\mathrm{Cr}_{2} \mathrm{Nb}$ will refer to the $\beta-\mathrm{Cr}_{2} \mathrm{Nb}$ phase in the following. 

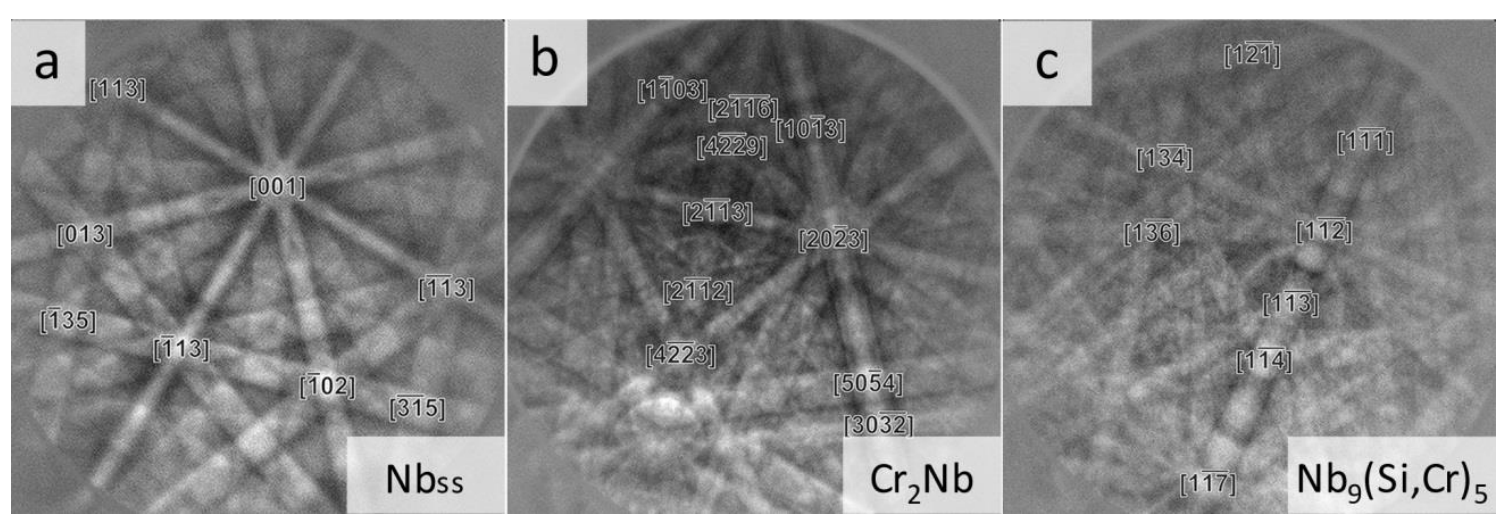

Figure 5: Indexed EBSD patterns of the phases present in Nb-10.9Si-28.4Cr: (a) $\mathrm{Nb}_{\mathrm{ss}}$ (b) $\mathrm{Cr}_{2} \mathrm{Nb}_{\text {b }}$ and (c) $\mathrm{Nb}_{9}(\mathrm{Si}, \mathrm{Cr})_{5}$.

\section{Phase stability}

For high temperature applications, microstructural as well as phase stability at and above service temperature is a crucial requirement. Therefore, the evolution of microstructural parameters such as phase fraction and size was examined after exposure to high temperatures. Besides long term stability $(500 \mathrm{~h})$ at $1200^{\circ} \mathrm{C}$ which may be a potential operation temperature for turbine applications higher temperatures $\left(1300^{\circ} \mathrm{C}\right.$ and $1500^{\circ} \mathrm{C}$ ) were also considered for shorter periods of time $(100 \mathrm{~h})$. Figure 6 shows the microstructure of $\mathrm{Nb}-10.9 \mathrm{Si}-28.4 \mathrm{Cr}$ in the as cast state as well as after such heat treatments. It is complemented by Figure 7 which illustrates the corresponding phase fractions and sizes.
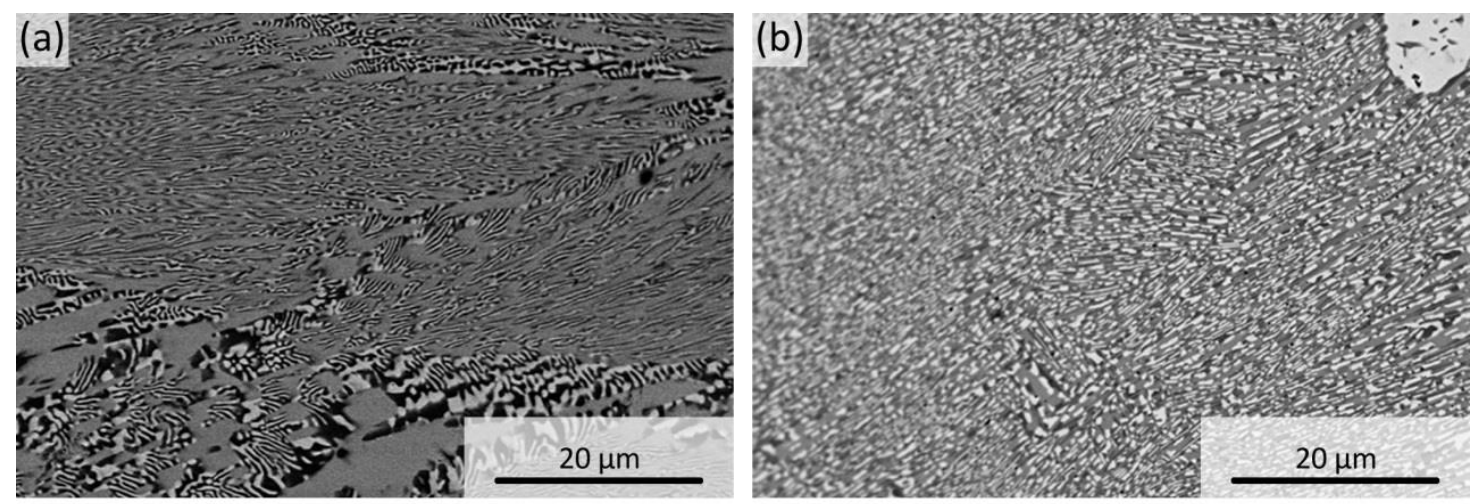

(c)
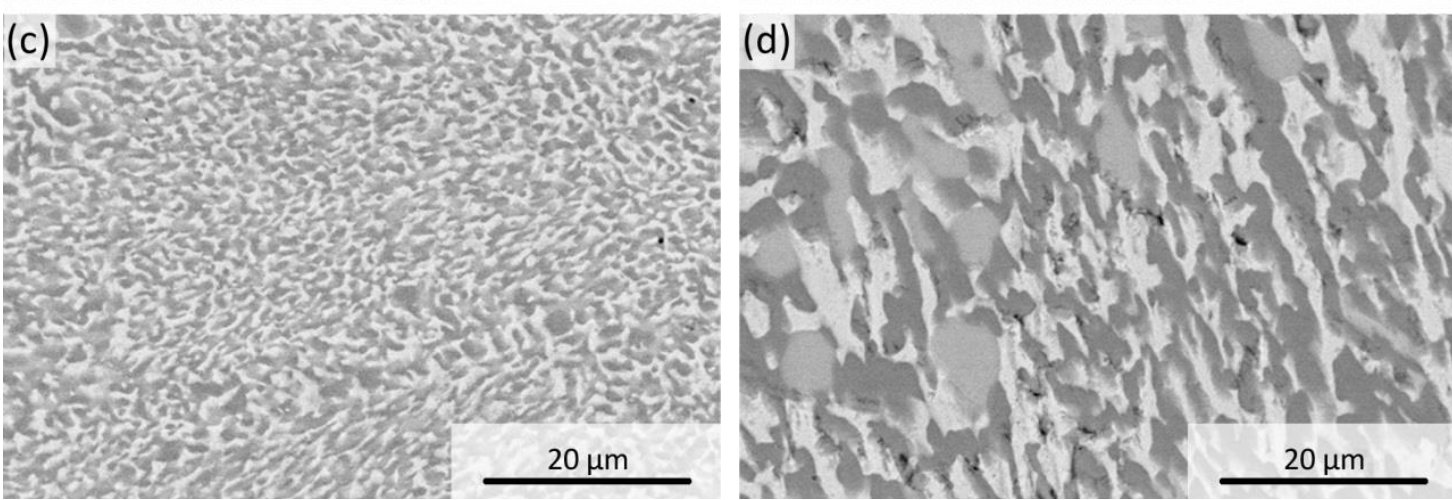

Figure 6: Phase evolution and stability in the alloy Nb-10.9Si-28.4Cr, starting from as cast state in (a) for different heat treatment conditions: (b) $1200^{\circ} \mathrm{C}, 500 \mathrm{~h}$; (c) $1300^{\circ} \mathrm{C}, 100 \mathrm{~h}$ and (d) $1500^{\circ} \mathrm{C}, 100 \mathrm{~h}$. 


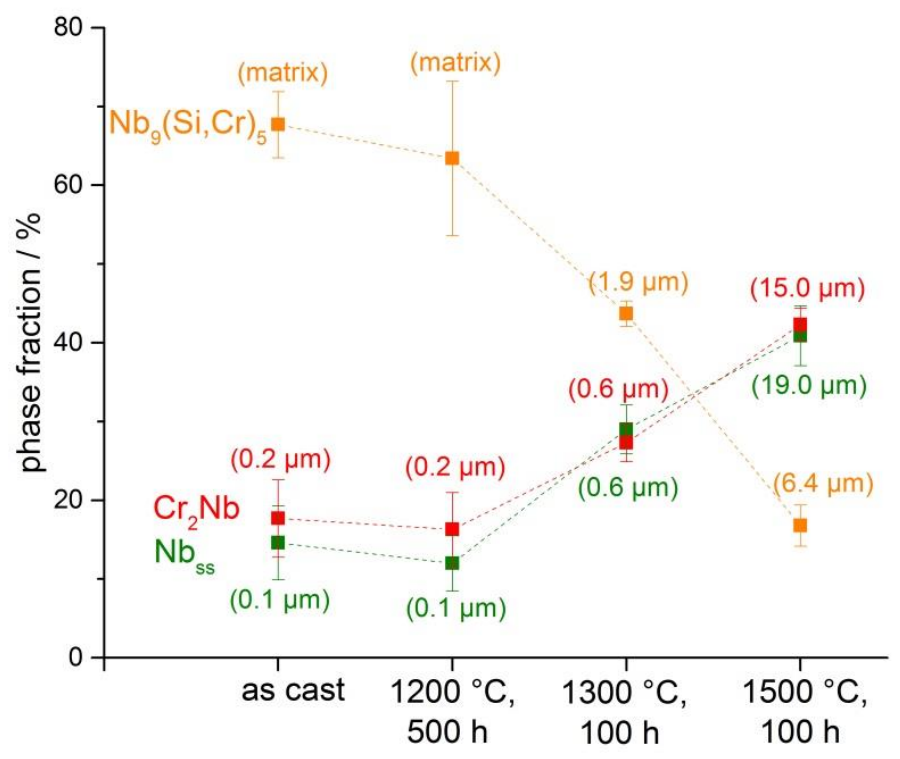

Figure 7: Evolution of phase fraction and -size in Nb-10.9Si-28.4Cr for different heat treatment conditions. Average phase size determined by segmentation of BSE images is provided in brackets. Connecting lines are to guide the eyes.

Compared to the as cast state, homogenization of the microstructure occurs for all heat treatment conditions. The inhomogeneous boundaries of the eutectic cells disappear. Apart from homogenization, the microstructure remains stable for up to $500 \mathrm{~h}$ at $1200{ }^{\circ} \mathrm{C}$. At $1300{ }^{\circ} \mathrm{C}$, slight coarsening of the phases is observed. The phase fraction of $\mathrm{Nb}_{9}(\mathrm{Si}, \mathrm{Cr})_{5}$ decreases significantly, while the amounts of $\mathrm{Nb}_{\mathrm{ss}}$ and $\mathrm{Cr}_{2} \mathrm{Nb}$ increase simultaneously and uniformly. Moreover, the silicide phase loses its matrix character. These effects are even more pronounced at $1500^{\circ} \mathrm{C}$. Hence, the examined alloy undergoes profound morphological changes during heat treatments. Especially the pronounced decrease of the silicide phase fraction and the simultaneous increase of $\mathrm{Nb}_{\mathrm{ss}}$ and $\mathrm{Cr}_{2} \mathrm{Nb}$ fractions are worth mentioning. As this effect might result from possible phase transformations, the local chemical composition was checked again after heat treatments. Results subsequent to annealing at $1500^{\circ} \mathrm{C}$ for $100 \mathrm{~h}$ are shown exemplarily in Table 4. Even though slight compositional variations have occurred in $\mathrm{Nb}_{\mathrm{ss}}$ and $\mathrm{Cr}_{2} \mathrm{Nb}$, these two phases are still present after heat treatment. In contrast, the silicide phase shows a significant change in terms of chemical composition. The Si content is increased to about 38 at.\% (as compared to roughly 16 at.\% in the as cast state). However, the $\mathrm{Cr}$ content has been reduced dramatically ( 1.5 at.\% as compared to 21 at.\%). Thus, the stoichiometry of the silicide phase hints for the presence of $\mathrm{Nb}_{5} \mathrm{Si}_{3}$ instead of $\mathrm{Nb}_{9}(\mathrm{Si}, \mathrm{Cr})_{5}$ after heat treatment. EBSD diffraction patterns presented in Figure 8 reveal that the silicide phase identified is the tetragonal $\alpha-\mathrm{Nb}_{5} \mathrm{Si}_{3}(\mathrm{tl} 32,14 / \mathrm{mcm}$ [15]). Figure $8 b$ demonstrates that this evolution into $\alpha-\mathrm{Nb}_{5} \mathrm{Si}_{3}$ is already active at temperatures as low as $1300^{\circ} \mathrm{C}$. 


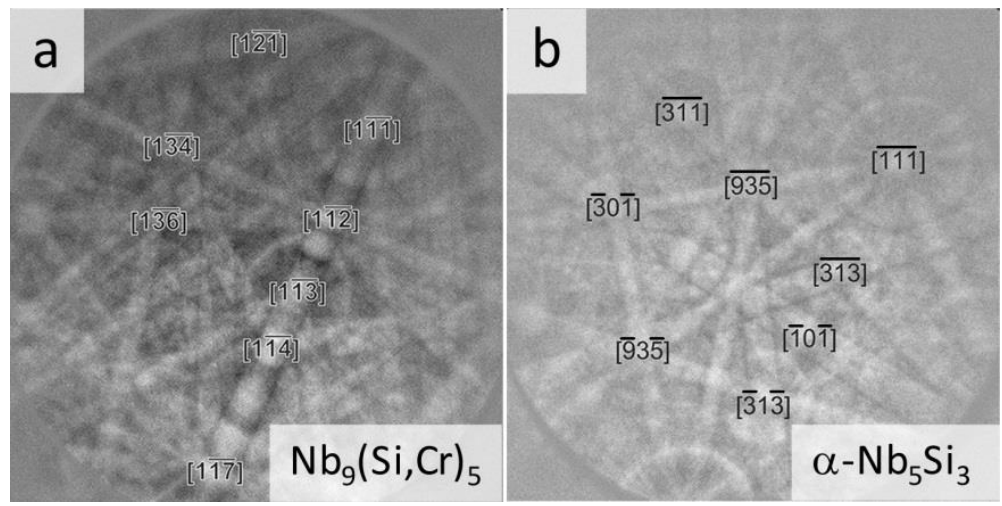

Figure 8: indexed EBSD diffraction patterns showing the silicide phase evolution in $\mathrm{Nb}-10.9 \mathrm{Si}-28.4 \mathrm{Cr}$ for different heat treatment conditions: (a) $\mathrm{Nb}_{9}(\mathrm{Si}, \mathrm{Cr})_{5}$ in as cast state and (b) $\alpha-\mathrm{Nb}_{5} \mathrm{Si}_{3}$ after $1300{ }^{\circ} \mathrm{C}, 100 \mathrm{~h}$

Attempts to address this solid-state reaction, e.g. by DSC measurements, were not successful so far. Nevertheless, as the transformation from $\mathrm{Nb}_{9}(\mathrm{Si}, \mathrm{Cr})_{5}$ to $a-\mathrm{Nb}_{5} \mathrm{Si}_{3}$ coincides with increasing phase fractions of $\mathrm{Nb}_{\mathrm{ss}}$ and $\mathrm{Cr}_{2} \mathrm{Nb}$, a eutectoid-like decomposition is conceivable. A eutectoid decomposition is already known from the $\mathrm{Nb}$-Si binary system, where $\mathrm{Nb}_{3} \mathrm{Si}$ decomposes into $\mathrm{Nb}_{\text {ss }}$ and $\mathrm{a}-\mathrm{Nb}_{5} \mathrm{Si}_{3}$ at $1763^{\circ} \mathrm{C}$ [16]. However, this solid-state reaction follows very slow kinetics [17], where a full eutectoid decomposition of $\mathrm{Nb}_{3} \mathrm{Si}$ cannot be achieved even after $1500^{\circ} \mathrm{C}$ for $500 \mathrm{~h}$ [18]. Hence, the absence of distinct reaction peaks during DSC measurements (not shown here) is not uncommon.

\section{Creep properties}

For high temperature applications, considerable slow creep deformation under constant load at homologous temperature $T / T_{m}>0.4$, where $T_{m}$ is the melting temperature, is one of the major design criteria for structural applications.

From previous results, the microstructure of the ternary eutectic appears to be stable in terms of phase fraction and size for temperatures up to $1200^{\circ} \mathrm{C}$, which might be a potential service temperature. Therefore, compressive creep tests were performed at this temperature on as cast material. The evolution of strain rate in dependence of true plastic strain is shown in Figure 9a. As soon as constant true stress was applied, a decrease in strain rate indicates initial strain hardening. This effect is more pronounced with decreasing true stress. The strain rates decrease until a minimum strain rate is reached at about $1 \%$ true plastic strain, which is similar for all true stresses tested. Immediately following the minimum, the strain rate slowly but continuously increases. Therefore, a stationary or so called "steady state" creep region where a dynamic equilibrium between strain hardening and recovery is established cannot be determined. Instead, a minimum creep rate has been defined at $1 \%$ plastic strain and is marked with red dots in Figure 9a. As true stress is applied in compression throughout the experiments and no significant microstructural changes were observed during creep (not shown here since similar to load-free heat treatment), only internal damage, e.g. cracking within the silicide or along the phase boundaries can cause the observed absence of stationary creep. This has already been reported by Bewlay et al. [19] and Seemueller et al. [20]. Even though cracking of the silicide, being still brittle at the temperature tested, is the most likely explanation for the observed effect, no significant damage could be observed, as the total strain achieved was $<2 \%$ and therefore very small. 
(a)

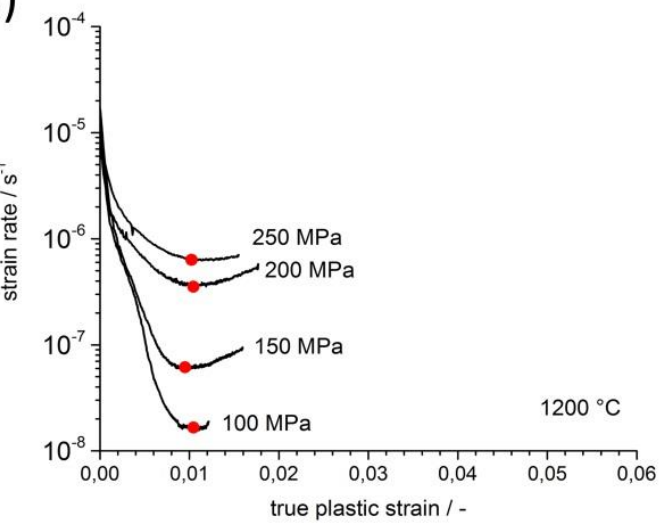

(b)

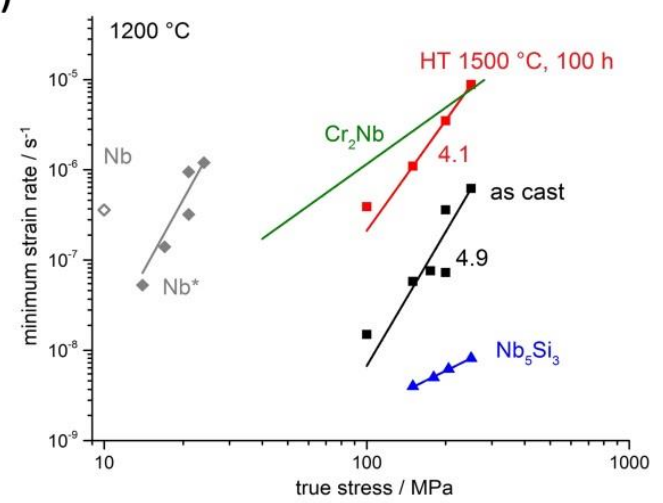

Figure 9: Stress dependence of the strain response for $\mathrm{Nb}-10.9 \mathrm{Si}-28.4 \mathrm{Cr}$, shown as (a) strain rate vs. true plastic strain (deliberately stopped subsequent to minimum) and (b) minimum strain rate vs. true stress (Norton plot). Data marked with “*” were determined at $1000^{\circ} \mathrm{C}$.

The Norton plot in Figure 9b depicts the minimum strain rate with respect to the applied true stress. For comparison, literature values of compressive creep data for monolithic $\mathrm{Nb}_{5} \mathrm{Si}_{3}$ [21] (as no literature data for $\mathrm{Nb}_{9}(\mathrm{Si}, \mathrm{Cr})_{5}$ is available), $\mathrm{Cr}_{2} \mathrm{Nb}$ [19] and pure $\mathrm{Nb}$ [22] were added. Data for $\mathrm{Nb}-10.9 \mathrm{Si}-28.4 \mathrm{Cr}$, heat treated at $1500^{\circ} \mathrm{C}$ for $100 \mathrm{~h}$ are included as well since this microstructure should be stable at the testing temperature of $1200^{\circ} \mathrm{C}$.

Surprisingly, the as cast condition, which according to Figure 7 has a substantially lower phase size than the heat treated condition, exhibits the lowest creep rates. An explanation for this effect can be found in the matrix character of the silicide phase $\mathrm{Nb}_{9}(\mathrm{Si}, \mathrm{Cr})_{5}$ after casting (phase fraction of $\approx 68 \%$ ). This phase carries the load, supports the substantially less creep resistant phases $\mathrm{Cr}_{2} \mathrm{Nb}$ and $\mathrm{Nb}_{\mathrm{ss}}$ and thus controls the creep resistance in the former case. The mitigation of $\mathrm{Nb}_{5} \mathrm{Si}_{3}$ creep properties by $\mathrm{Nb}_{\mathrm{ss}}$ using a rule of mixture approach could explain the intermediate position obtained for $\mathrm{Nb}-10.9 \mathrm{Si}$ 28.4Cr. Simulation based on such approach in binary $\mathrm{Nb}$-Si alloys, consisting of $\mathrm{Nb}_{\mathrm{ss}}$ and $\mathrm{Nb}_{5} \mathrm{Si}_{3}$, showing similar results, were already published $[23,24]$. On the other hand, a difference in $\mathrm{Nb}_{9}(\mathrm{Si}, \mathrm{Cr})_{5}$ creep strength in the present alloy compared to monolithic $\mathrm{Nb}_{5} \mathrm{Si}_{3}$ may also explain strain rate variations.

Increased strain rates obtained for heat treated conditions could be attributed to the decreasing fraction of the silicide phase and the loss of its matrix character. This influence of the silicide phase fraction on the creep behavior has already been published in the literature for quaternary Nb-Si-Ti-Hf alloys [19]. The minimum strain rates shown in Figure $9 \mathrm{~b}$ approach the values of the other phases involved in the microstructure, mainly the ones for $\mathrm{Cr}_{2} \mathrm{Nb}$. Due to the interpenetrating eutectic character of the microstructure, and since $\mathrm{Nb}_{\mathrm{ss}}$ has no significant creep resistance at the present stress levels and temperature, the Laves phase $\mathrm{Cr}_{2} \mathrm{Nb}$ carries the major part of load during creep and therefore determines the overall creep resistance of the alloy.

Stress exponents for both material conditions are in the order of magnitude expected for dislocation creep $(n=3-8)$. Supporting this finding, dislocation climb controlled creep has not only been reported in $\mathrm{Nb}$ and $\mathrm{Cr}_{2} \mathrm{Nb}$ at temperatures above $1200{ }^{\circ} \mathrm{C}$ [25], but also for $\mathrm{Nb}_{3} \mathrm{Si}$ [26]. Hence, the assumption of dislocation creep in the present silicide phase $\mathrm{Nb}_{9}(\mathrm{Si}, \mathrm{Cr})_{5}$ seems legitimate, even though no data for this monolithic phase are available.

Finally, the data obtained for $\mathrm{Nb}-10.9 \mathrm{Si}-28.4 \mathrm{Cr}$ are compared to compressive creep data for other refractory based silicides, as well as a state of the art Ni-based superalloy tested in tension, from the literature, in a density-normalized Norton plot in Figure 10, in order to critically assess the potential of the ternary eutectic alloy. 


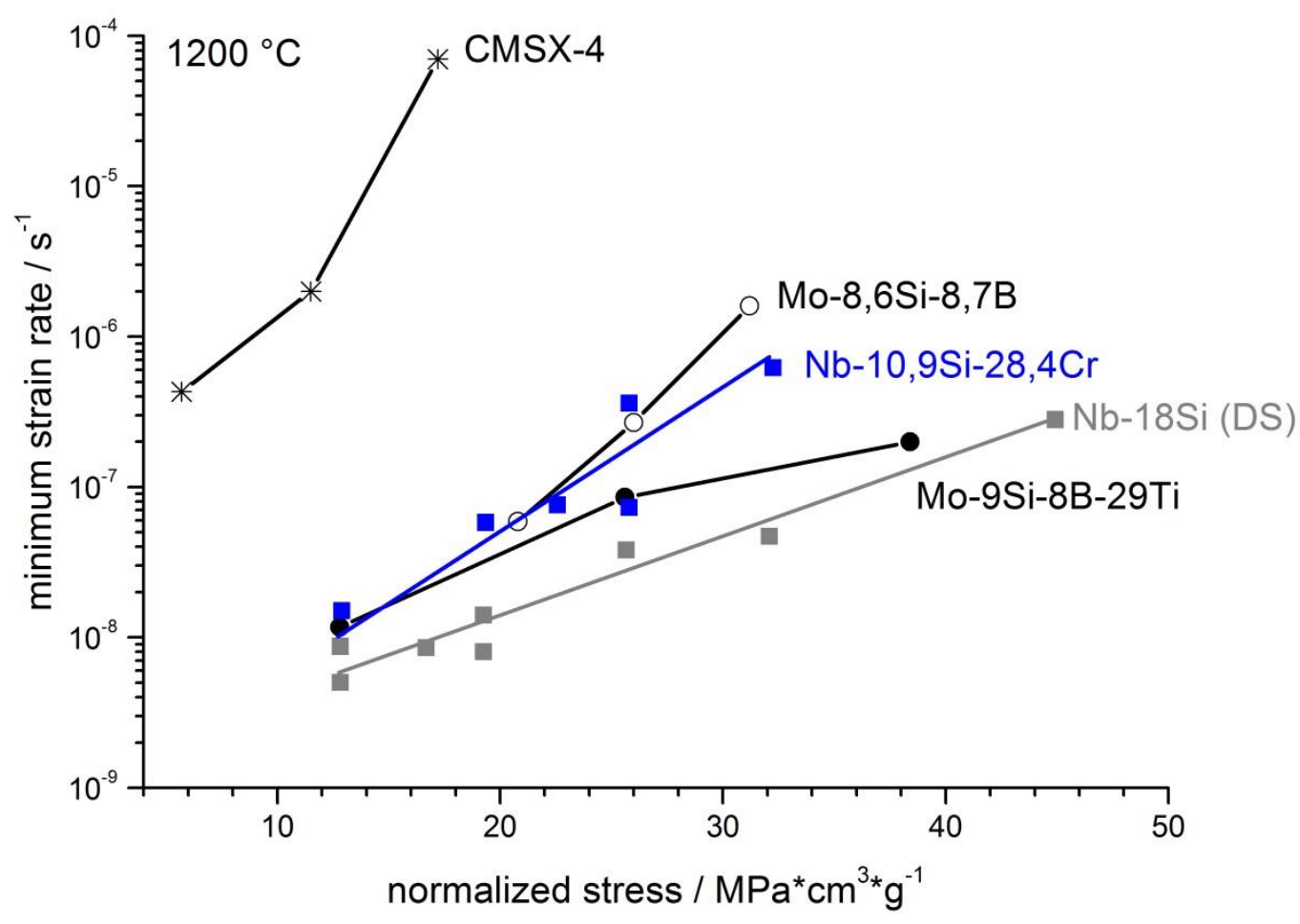

Figure 10: Density-normalized Norton plot, showing the potential of $\mathrm{Nb}-10.9 \mathrm{Si}-28.4 \mathrm{Cr}$ when compared to other refractory metals based alloys as well as $\mathrm{Ni}$-based superalloys.

The minimum strain rates for $\mathrm{Nb}-10.9 \mathrm{Si}-28.4 \mathrm{Cr}$ are comparable with molybdenum silicides $\mathrm{Mo}-8.6 \mathrm{Si}-$ 8.7B [27] and Mo-9Si-8B-29Ti [28] in the measurement uncertainty range. When compared to directionally solidified $\mathrm{Nb}$-18Si [3], the fraction of load-bearing silicide phases is similar $(\approx 66 \%$ for $\mathrm{Nb}$ $18 \mathrm{Si}$ versus $\approx 68 \%$ for $\mathrm{Nb}-10.9 \mathrm{Si}-28.4 \mathrm{Cr}$ ). Hence the strain rate difference of one order of magnitude can be attributed to the phase alignment along the loading direction. Compared to the single-crystal Ni-based superalloy CMSX-4 [29], all refractory based alloys have up to two orders of magnitude lower strain rates. This is not surprising, as the testing temperature of $1200^{\circ} \mathrm{C}$ is in the temperature range of $y^{\prime}$ solvus in Ni-based superalloys, which leads to a significant loss of particle strengthening in these alloys.

\section{Conclusions}

The chemical composition of the $\mathrm{Nb}$-rich ternary eutectic in the system $\mathrm{Nb}-\mathrm{Si}-\mathrm{Cr}$ was experimentally determined to be $\mathrm{Nb}-10.9 \mathrm{Si}-28.4 \mathrm{Cr}$. The phases present in the as cast state are $\mathrm{Nb}_{\mathrm{ss}}$, $\beta-\mathrm{Cr}_{2} \mathrm{Nb}$ and $\mathrm{Nb}_{9}(\mathrm{Si}, \mathrm{Cr})_{5}$, the later forming an interpenetrating matrix. Microstructure and phase stability could be confirmed up to $1200^{\circ} \mathrm{C}$ for several hundred hours. At this temperature, creep properties are comparable to other refractory based silicide alloys, dislocation controlled creep being the predominant mechanism. As compared to CMSX-4, significantly improved creep strength could be observed. However, above $1200^{\circ} \mathrm{C}$, the $\mathrm{Nb}_{9}(\mathrm{Si}, \mathrm{Cr})_{5}$ undergoes a presumably eutectoid-like decomposition into $\mathrm{Nb}_{\mathrm{ss}}, \beta-\mathrm{Cr}_{2} \mathrm{Nb}$ and $\alpha-\mathrm{Nb}_{5} \mathrm{Si}_{3}$. Because of this decomposition, $\mathrm{Nb}-10.9 \mathrm{Si}-28.4 \mathrm{Cr}$ loses its load-bearing $\mathrm{Nb}_{9}(\mathrm{Si}, \mathrm{Cr})_{5}$ matrix, which results in a significant loss of creep strength. Therefore the temperature limit for structural applications is currently set below $1300^{\circ} \mathrm{C}$. To overcome this limitation, more profound knowledge of the decomposition process is necessary. So far, employing available analyzing methods (e.g. DSC) could not yield information on both the exact transformation path and the reversibility of the process. Moreover, it has to be clarified, whether $\mathrm{Nb}_{9}(\mathrm{Si}, \mathrm{Cr})_{5}$ may 
possibly be a metastable high temperature phase. Finding answers to these questions is part of ongoing research. Eventually, ways can be found to suppress either its formation or decomposition. As stated previously, this ternary alloy in theory should exhibit well-balanced creep, oxidation and fracture toughness properties. However, the two later properties have not been addressed so far and should be thoroughly assessed in future work, to explore the capability and applicability of a ternary eutectic $\mathrm{Nb}-\mathrm{Si}-\mathrm{Cr}$ alloys.

\section{Acknowledgements}

Financial support by the German science foundation (DFG) under grant no.'s HE1872/19-1 and -2 is gratefully acknowledged. Moreover, the authors would like to thank Frank Stein and Martin Palm from Max-Planck-Institut für Eisenforschung, Duesseldorf, Germany, as well as Georg Hasemann from Forschungszentrum Juelich for fruitful discussions on ternary eutectics. Moreover, support by the colleagues from Duesseldorf in terms of WDS measurements is gratefully acknowledged.

The authors would also like to thank Fabia Suess for experimental support. This work was partly carried out with the support of the Karlsruhe Nano Micro Facility (KNMF, www.knmf.kit.edu), a Helmholtz Research Infrastructure at Karlsruhe Institute of Technology (KIT, www.kit.edu). AK thanks the Carl Zeiss Foundation for financial support through a postdoc grant.

\section{References}

[1] J.-C. Zhao, J. H. Westbrook, MRS Bulletin 2003 (11), 622 - 630.

[2] B. P. Bewlay, M. Jackson, J.-C. Zhao, P. R. Subramanian, Metall. Mater. Trans. A 2003, 34A (10), $2043-2052$.

[3] F. Gang, M. Heilmaier, JOM 2014, 66 (9), 1908 - 1913. DOI: 10.1007/s11837-014-1109-6.

[4] N. Sekido, Y. Kimura, Y. Mishima, Mat. Res. Soc. Symp. Proc 2003, 753, BB5.25.1-6.

[5] K. Zelenitsas, P. Tsakiropoulos, Intermetallics 2005, 13 (10), 1079- 1095. DOI: 10.1016/j.intermet.2005.02.002.

[6] J. Geng, P. Tsakiropoulos, G. Shao, Materials Science and Engineering: A 2006, 441 (1-2), 26 38. DOI: 10.1016/j.msea.2006.08.093.

[7] J. Geng, P. Tsakiropoulos, Intermetallics 2007, 15 (3), 382 - 395. DOI: 10.1016/j.intermet.2006.08.016.

[8] J. Geng, P. Tsakiropoulos, G. Shao, Intermetallics 2007, 15 (3), $270-281$. DOI: 10.1016/j.intermet.2006.06.003.

[9] B. Khazai, R. Kershaw, K. Dwight, A. Wold, J. Solid State Chem. 1981, 39, $395-400$.

[10] G. Shao, Intermetallics 2005, 13 (1), 69 - 78. DOI: 10.1016/j.intermet.2004.06.003.

[11] B. P. Bewlay, Y. Yang, R. L. Casey, M. R. Jackson, Y. A. Chang, Intermetallics 2009, 17 (3), 120 127. DOI: $10.1016 /$ j.intermet.2008.10.005.

[12] L. Cornish, D. M. Cupid, J. Gröbner, A. Malfliet, Cr-Nb-Si Ternary Phase Diagram Evaluation, http://materials.springer.com/msi/docs/sm_msi_r_10_010543_01 2010.

[13] J.-C. Zhao, M. Jackson, L. Peluso, Acta Materialia 2003, 51 (20), 6395 - 6405. DOI: 10.1016/j.actamat.2003.08.007.

[14] P. Villars, L. D. Calvert, Pearson's handbook of crystallographic data for intermetallic phases: Vol. 3: $\mathrm{Cr}_{2} \mathrm{Nb}-\mathrm{In}_{2} \mathrm{P}_{3} \mathrm{Se}_{9}$, ASM International, Materials Park, Ohio 1991.

[15] J. Geng, Development of niobium silicide based in situ composites: Next generation materials for high temperature applications, LAP Lambert Academic Publishing, Saarbrücken 2009. 
[16] B. Predel, Nb-Si (Niobium-Silicon): Landolt-Börnstein - Group IV Physical Chemistry 5H Li-Mg Nd-Zr, Berlin, Heidelberg, http://materials.springer.com/lb/docs/sm_lbs_978-3-540-68538-8_ 21951997.

[17] M. E. Schlesinger, H. Okamoto, A. B. Gokhale, R. Abbaschian, JPE 1993, 14 (4), $502-509$. DOI: $10.1007 / B F 02671971$.

[18] M. G. Mendiratta, D. M. Dimiduk, Scr Metall. Mater. 1991, 25, 237 - 242.

[19] B. P. Bewlay, C. L. Briant, A. W. Davis, M. R. Jackson, Mat. Res. Soc. Symp. Proc 2001 (646), N.2.7.1-N.2.7.6.

[20] C. Seemüller, M. Heilmaier, T. Hartwig, M. Mulser, N. Adkins, M. Wickins, Mat. Res. Soc. Symp. Proc 2013, 1516, 317 - 322.

[21] P. R. Subramanian, T. A. Parthasarathy, M. G. Mendiratta, D. M. Dimiduk, Scr Metall. Mater. 1995, 32 (8), $1227-1232$.

[22] G. Brinson, B. B. Argent, J. Inst. Met. 1962/63 (91), $293-298$.

[23] K. S. Chan, Materials Science and Engineering: A 2002, 337 (1-2), 59 - 66. DOI: 10.1016/S09215093(02)00011-4.

[24] G. A. Henshall, P. R. Subramanian, M. J. Strum, M. G. Mendiratta, Acta Materialia 1997, 45 (8), $3135-3142$.

[25] M. Yoshida, T. Takasugi, Intermetallics 2002, 10 (1), 85 - 93. DOI: 10.1016/S09669795(01)00107-8.

[26] B. P. Bewlay, C. L. Briant, E. T. Sylven, M. R. Jackson, Mat. Res. Soc. Symp. Proc 2003 (753), BB5.24.1-BB5.24.6.

[27] P. Jain, K. S. Kumar, Acta Materialia 2010, 58 (6), 2124 - 2142. DOI: 10.1016/j.actamat.2009.11.054.

[28] D. Schliephake, M. Azim, K. von Klinski-Wetzel, B. Gorr, H.-J. Christ, H. Bei, E. P. George, M. Heilmaier, Metall and Mat Trans A 2014, 45 (3), 1102 - 1111. DOI: 10.1007/s11661-013-1944z.

[29] M. Heilmaier, M. Krüger, H. Saage, J. Rösler, D. Mukherji, U. Glatzel, R. Völkl, R. Hüttner, G. Eggeler, C. Somsen, T. Depka, H.-J. Christ, B. Gorr, S. Burk, JOM 2009, 61 (7), 61 - 67. DOI: 10.1007/s11837-009-0106-7. 
Table 1: Nominal and actual composition of the alloys used for triangulation. The numbers shown in Figure 2 are matched to the compositions accordingly.

\begin{tabular}{lll}
\hline alloy no. & nominal & actual (ICP-OES) \\
\hline $\mathbf{1}$ & $\mathrm{Nb}-8.7 \mathrm{Si}-33.1 \mathrm{Cr}$ & $\mathrm{Nb}-9.0 \mathrm{Si}-33.3 \mathrm{Cr}$ \\
$\mathbf{2}$ & $\mathrm{Nb}-12 \mathrm{Si}-25 \mathrm{Cr}$ & $\mathrm{Nb}-12.5 \mathrm{Si}-26 \mathrm{Cr}$ \\
$\mathbf{3}$ & $\mathrm{Nb}-8.7 \mathrm{Si}-22 \mathrm{Cr}$ & $\mathrm{Nb}-7.8 \mathrm{Si}-21.9 \mathrm{Cr}$ \\
$\mathbf{4}$ & $\mathrm{Nb}-12 \mathrm{Si}-33.1 \mathrm{Cr}$ & $\mathrm{Nb}-12.4 \mathrm{Si}-33.2 \mathrm{Cr}$ \\
\hline
\end{tabular}

Table 2: Quantitative EDS results for the ternary eutectic structures

\begin{tabular}{lllll}
\hline alloy no. & alloy composition & $\mathrm{Nb} /$ at. $\%$ & $\mathrm{Si} /$ at.\% & $\mathrm{Cr} /$ at.\% \\
\hline $\mathbf{3}$ & $\mathrm{Nb}-8.7 \mathrm{Si}-22 \mathrm{Cr}$ & $60.7 \pm 0.1$ & $11.0 \pm 0.5$ & $28.3 \pm 0.5$ \\
$\mathbf{4}$ & $\mathrm{Nb}-12 \mathrm{Si}-33.1 \mathrm{Cr}$ & $60.7 \pm 0.1$ & $10.8 \pm 0.6$ & $28.5 \pm 0.4$ \\
\hline
\end{tabular}

Table 3: Chemical composition of the phases in Nb-10.9Si-28.4Cr in the as cast state.

\begin{tabular}{llll}
\hline phase & $\mathrm{Nb} /$ at. $\%$ & $\mathrm{Si} /$ at.\% & $\mathbf{C r} /$ at.\% \\
\hline $\mathbf{N b}_{\text {ss }}$ & $84.6 \pm 2.5$ & $2.4 \pm 0.8$ & $13.0 \pm 2.0$ \\
$\mathbf{C r}_{2} \mathbf{N b}$ & $39.9 \pm 2.3$ & $12.6 \pm 0.9$ & $47.5 \pm 1.6$ \\
$\mathbf{N b}_{9}(\mathrm{Si}, \mathrm{Cr})_{5}$ & $62.8 \pm 1.3$ & $16.2 \pm 0.4$ & $21.0 \pm 1.6$ \\
\hline
\end{tabular}

Table 4: Chemical composition of the phases present in Nb-10.9Si-28.4Cr after heat treatment at $1500{ }^{\circ} \mathrm{C}$ for $100 \mathrm{~h}$.

\begin{tabular}{llll}
\hline phase & $\mathbf{N b} /$ at.\% & Si / at.\% & $\mathbf{C r} /$ at.\% \\
\hline $\mathrm{Nb}_{\text {ss }}$ & $89.9 \pm 0.2$ & $0.4 \pm 0.1$ & $9.7 \pm 0.2$ \\
$\mathbf{C r}_{2} \mathbf{N b}$ & $33.8 \pm 0.2$ & $12.4 \pm 0.3$ & $53.7 \pm 0.4$ \\
Silicide & $60.5 \pm 0.1$ & $38.0 \pm 0.2$ & $1.5 \pm 0.1$ \\
\hline
\end{tabular}


Figures

Figure 1: SEM-BSE micrographs of the alloys (a) Nb-12Si-25Cr and (b) $\mathrm{Nb}-8.7 \mathrm{Si}-33.1 \mathrm{Cr}$, both in as cast condition

Figure 2: Partial liquidus projection of the $\mathrm{Nb}-\mathrm{Si}-\mathrm{Cr}$ system, including isothermal lines (calculated with PANDAT employing the PanNb database). Compositions according to the numbers are listed in Table 1. The red dots symbolize the nominal composition; blue ones represent the actual composition.

Figure 3: SEM-BSE micrographs of the alloys (a) Nb-8.7Si-22Cr and (b) Nb-12Si-33.1Cr. In both alloys ternary eutectic structures can be observed (marked with a red circle).

Figure 4: Micrographs of the ternary eutectic alloy Nb-10.9Si-28.4Cr: (a-b) SEM-BSE mode and (c) EBSD, false-color image of the phases $\mathrm{Nb9}(\mathrm{Si}, \mathrm{Cr})_{5}$ (yellow), Nbss (green) and $\mathrm{Cr} 2 \mathrm{Nb}$ (red).

Figure 5: Indexed EBSD patterns of the phases present in Nb-10.9Si-28.4Cr: (a) Nbss, (b) Cr2Nb and (c) $\mathrm{Nb9}(\mathrm{Si}, \mathrm{Cr})_{5}$.

Figure 6: Phase evolution and stability in the alloy $\mathrm{Nb}-10.9 \mathrm{Si}-28.4 \mathrm{Cr}$, starting from as cast state in (a) for different heat treatment conditions: (b) $1200^{\circ} \mathrm{C}, 500 \mathrm{~h}$; (c) $1300^{\circ} \mathrm{C}, 100 \mathrm{~h}$ and (d) $1500^{\circ} \mathrm{C}, 100 \mathrm{~h}$.

Figure 7: Evolution of phase fraction and -size in Nb-10.9Si-28.4Cr for different heat treatment conditions. Average phase size determined by segmentation of BSE images is provided in brackets. Connecting lines are to guide the eyes.

Figure 8: indexed EBSD diffraction patterns showing the silicide phase evolution in $\mathrm{Nb}-10.9 \mathrm{Si}-28.4 \mathrm{Cr}$ for different heat treatment conditions: (a) $\mathrm{Nb9}(\mathrm{Si}, \mathrm{Cr})_{5}$ in as cast state and (b) $\alpha-\mathrm{Nb} 5 \mathrm{Si} 3$ after $1300{ }^{\circ} \mathrm{C}$, $100 \mathrm{~h}$

Figure 9: Stress dependence of the strain response for $\mathrm{Nb}-10.9 \mathrm{Si}-28.4 \mathrm{Cr}$, shown as (a) strain rate vs. true plastic strain (deliberately stopped subsequent to minimum) and (b) minimum strain rate vs. true stress (Norton plot). Data marked with "*” were determined at $1000^{\circ} \mathrm{C}$.

Figure 10: Density-normalized Norton plot, showing the potential of $\mathrm{Nb}-10.9 \mathrm{Si}-28.4 \mathrm{Cr}$ when compared to other refractory metals based alloys as well as Ni-based superalloys. 